\title{
Synthesis of Some 1, 3, 4- Oxadizole Derivatives From Naproxen and Acetyl Chloride
}

\author{
Alya A. Dawood \\ Chemistry Department / College of Science \\ University of Zakho
}

Received

04 / 09 / 2011
Accepted

$02 / 11 / 2011$

\begin{abstract}
الخلاصة
في هذا البحث تم تحضير عدد من المركبات 4,3,1- اوكسادايازول -2- ثايون من الإني

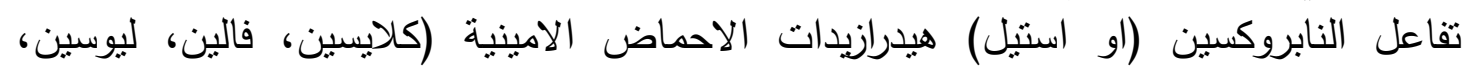

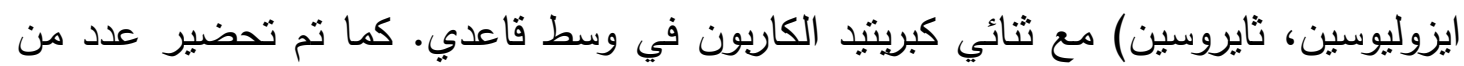

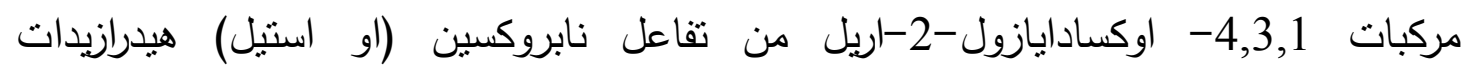

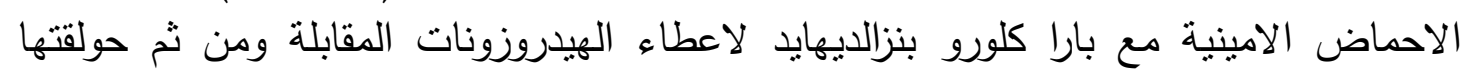

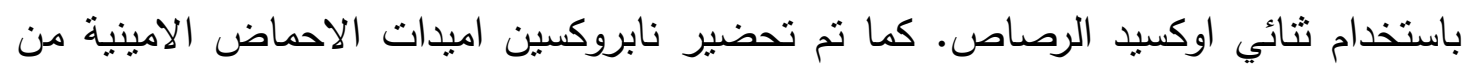

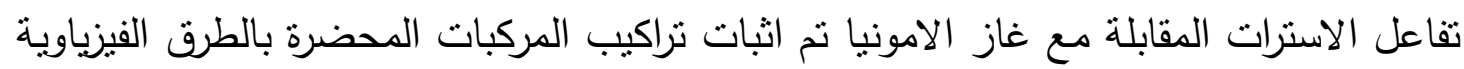
والطيفية.
\end{abstract}

\section{Abstract}

A seriers of 1, 3, 4-oxadiazol-2-thion were synthesized by the reaction of naproxen (or acetyl) amino acid hydrazides (glycine, valine, leucine, isoleucine and tyrosine) with carbon disulphide in alkaline medium. The reaction of naproxen (or acetyl) amino acid hydrazides were treated with p-chloro benzaldehyde to give hydrazone, the hydrazones were then cyclized with lead dioxide to give 1, 3, 4-oxadiazol-2-aryl. Naproxen amino acid esters were treated with ammonia gas to give naproxen amino acid amids. The synthesized compounds were characterized by physical and spectral analysis.

\section{Introduction}

In the family of heterocyclic compounds, nitrogen containing heterocycles with an oxygen atom are considered to be an important class of compounds in medicinal chemistry because of their interesting diversified biological application. The oxadiazole derivatives have been reported to have various biological activites including anti-microbal (1-3), anticancer (4, 5), anti inflammatory (6), anti-infective (7), and anti HIV (8). Substituted oxadiazole moiety has also been found to have other important activites such as antiviral (9), antifungal (10-12), antimycobacterial (13), anticouvulsant (14), antitumor (15), antimarlarial (16), and anti-hepatitis B viral activities (17). Substituted 1, 3, 4oxadiazoles exhibit antibacterial (18-19), pesticidal (20) and analgesic activities (21-22). This paper describes the synthesis of new heterocyclic systems containing 1, 3, 4- oxadiazoles linked with naproxen. 


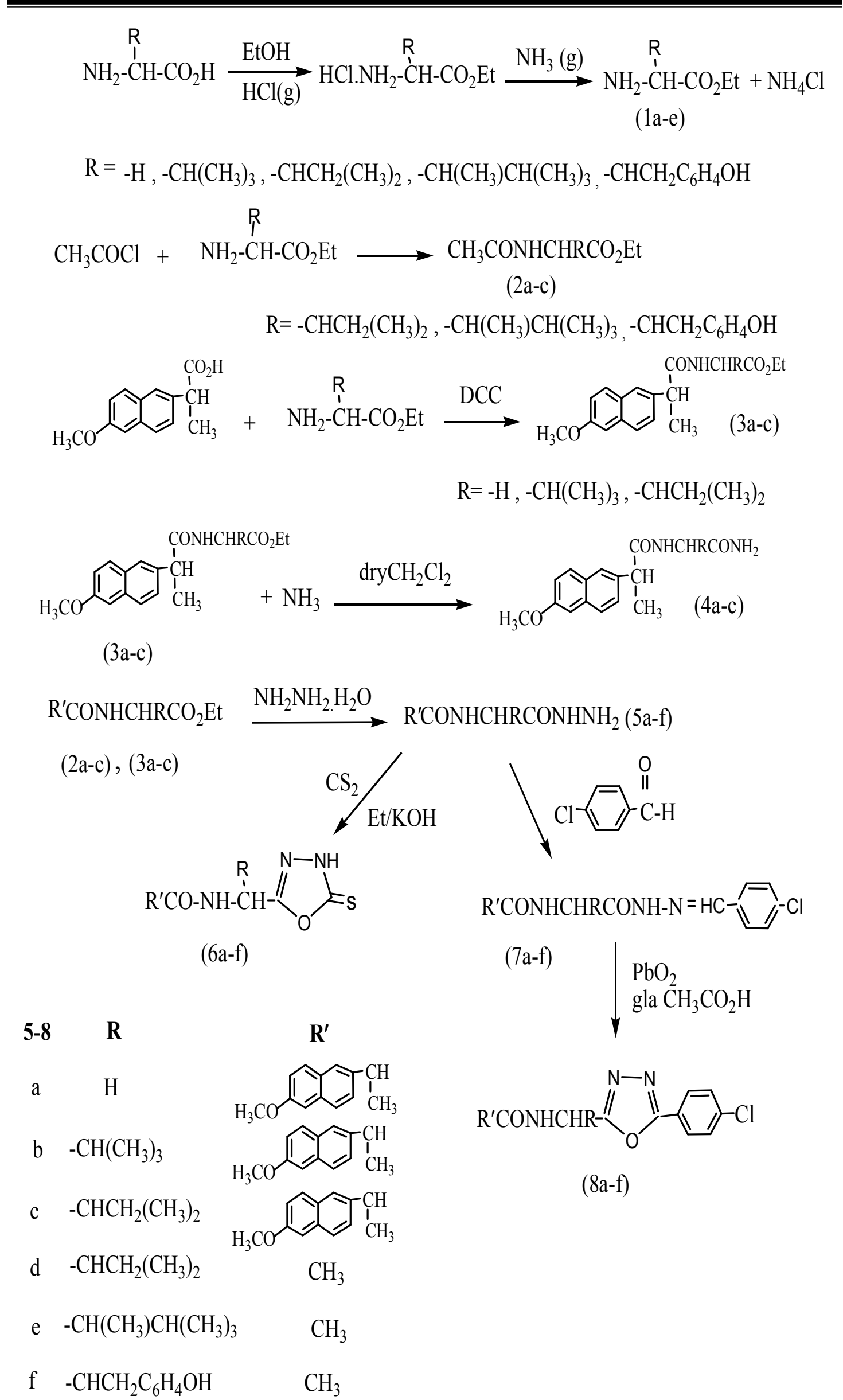




\section{Experimental}

The melting points were measured on Bibby Scien Tific Limited, ST15 0SA, UK. IR spectra were recorded on FT-IR Spectrometer model Spectrum One, Perkin Elmer., using KBr discs. UV spectra were recorded on Lnicam, Disc PD2000-1, Mini Sipper Compot Tible. Amino acid esters (1a-e), acetyl amino acid esters (2a-c) and acetyl amino acid hydrazide (5d-f) were prepared using a previously reported method ${ }^{(23)}$.

\section{Synthesis of Naproxen Amino Acid Ester (3a-c)}

To solution of $0.01 \mathrm{M}$ of Naproxen and $0.01 \mathrm{M}$ of amino acid ester in $(50 \mathrm{ml})$ of dichloromethane is added $0.01 \mathrm{M}$ of $\mathrm{N}, \mathrm{N}$-dicyclo hexyl carbodiimide (DCC), The mixture is allowed to stirring over night at room temperature, The precipitated dicyclo hexyl urea is removed by filtration and the filtrate washed with water, diluted hydrochloric acid, water, half saturated sodium bicarbonate solution, water, and finally dried over anhydrous sodium sulfate, evaporation of the solvent gives residue mixture of crystals and oil. These are treated with a small amount of ether and filtrate; although the material is quite soluble in ether and hence is lost in appreciable amount when this solvent is employed, the white precipitate is recrystallized from chloroform. (Table 1)

\section{Synthesis of Naproxen Amino Acid Amide (4a-c)}

A stream of dry ammonia gas was passed through a solution of naproxen amino acid ester $(0.01$ mole $)$ in $50 \mathrm{ml}$ of dichloro methane. The ammonium chloride was filtered off, the solvent was evaporated under reduced pressure, physical and spectral data are illustrated in (Table1).

\section{Synthesis of Naproxen Amino Acid Hydrazide (5a-c)}

A mixture of naproxen (or acetyl) amino acid ester $(0.01$ mole) and hydrazine hydrate $(0.2$ mole $)$ in absolute ethanol $(50 \mathrm{ml})$ was refluxed for 2 hrs. The mixture was cooled and the solid was filtered, dried and recrystallized from ethanol.

\section{Synthesis of 1, 3, 4- Oxadiazole-2-Thione (6a-f)}

To a mixture of (0.005 mole) naproxen (or acetyl) amino acid hydrazide (5a-f) in $50 \mathrm{ml}$ of alcoholic potassium hydroxide solution $(0.5 \%)$ was added slowly $(12 \mathrm{ml}) \mathrm{CS}_{2}$. After that the mixture was refluxed for 12 hours until the liberation of hydrogen sulfide was ceased (checked by moist paper with lead acetate). The solution was evaporated and the residual was poured on crushed ice, acidify with diluted $\mathrm{HCl}$, filtered and dried.(Table 2).

\section{Synthesis of Naproxen (or Acetyl) Amino Acid p-Chlorophenyl Hydrazones (7a-f)}

P-chloro benzaldehyde (0.01 mole), naproxen (or acetyl) amino acid hydrazide $(0.01$ mole $)$ in $50 \mathrm{ml}$ of ethanol was refluxed for $2 \mathrm{hrs}$. 
The solvent was condensed, and then the precipitate was filtered and recrystallized from benzene. (Table 2)

\section{Synthesis of 1, 3, 4- Oxadiazole-2- Aryl (8a-f)}

To a homogenous solution of hydrazones $(7 \mathrm{a}-\mathrm{f})(0.01 \mathrm{~mole})$ in 20 $\mathrm{ml}$ of glacial acetic acid, $\mathrm{PbO}_{2}(0.01$ mole) was added to the reaction mixture and stirred with mechanical stirrer at $25^{\circ} \mathrm{C}$ for $1 \mathrm{hrs}$. The reaction mixture was diluted with ice-water and left to stand for $24 \mathrm{hrs}$. The precipitate was filtered and recrystallized from benzene. (Table 2)

\section{Results and discussion}

Naproxen amino acid esters (3a-c) were synthesized from the reaction of naproxen and amino acid esters. Their IR spectra (Table1) shows the main absorption bands at $3306-3287 \mathrm{~cm}^{-1}$ for NH amide, 1710$1747 \mathrm{~cm}^{-1}$ for CO ester and 1670-1673 $\mathrm{cm}^{-1}$ for CONH stretching absorption. Naproxen amino acid amides (4a-c) synthesized through passing ammonia gas to a solution of naproxen amino acid esters in dichloro methane. They were characterized by the following absorption bands (Table2) $3303-3331 \mathrm{~cm}^{-1}$ for NH stretching vibration and $1673 \mathrm{~cm}^{-1}$ for $\mathrm{CONH}$ stretching vibration of amide in addition to absent of $\mathrm{C}=\mathrm{O}$ ester stretching vibration.

Naproxen amino acid hydrazides (5a-c) were synthesized from the corresponding esters with hydrazine hydrate in absolute ethanol. The IR spectra shows the following main signals $3297-3331 \mathrm{~cm}^{-1}$ for $\mathrm{NH}, 1627-$ $1652 \mathrm{~cm}^{-1}$ for $\mathrm{C}=\mathrm{O}$ stretching vibration.

Oxadiazoles have been prepared by many procedures (24-27). However in this investigation the preparation of oxadiazoles were achieved by two procedures. The first was performed by the reaction of hydrazides and carbon disulfide in alkaline medium. The mechanism of the reaction is accomplished by nucleophilic attack of the enol hydrazide form at the carbon atom of carbon disulfide. The formed xanthat salts underwent intra nucleophilic attack followed by hydrogen sulfide elimination to give oxadiazol -2-thione (28).

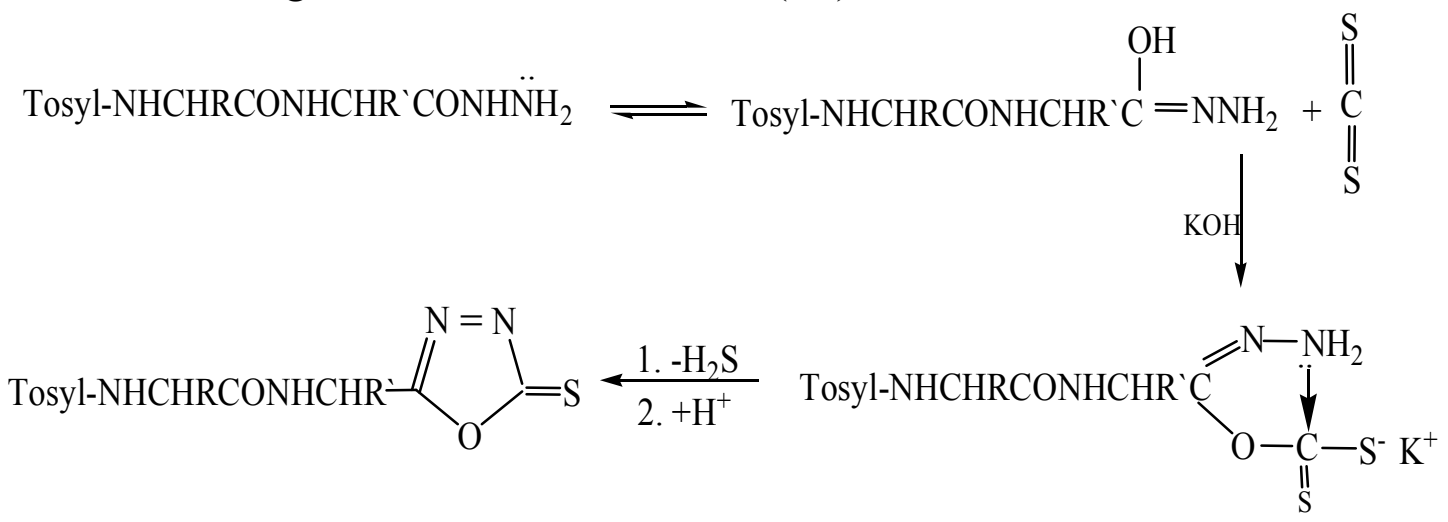


The IR spectra of compounds (6a-f) showed absorption bands at $3297-3444 \mathrm{~cm}^{-1}$ corresponds to the NH stretching vibration, and others gave the following vibrational absorption bands (1629-1702), (16051656), (1213-1295) and (1117-1196) $\mathrm{cm}^{-1}$ which are assigned to $(\mathrm{C}=\mathrm{O})$, $(\mathrm{C}=\mathrm{N}),(\mathrm{C}-\mathrm{O}-\mathrm{C})$ and $(\mathrm{C}=\mathrm{S})$, respectively.

The second pathway of synthesis was by the reaction of hydrazide (5a-f) with p-chloro benzaldehyde to give the hydrazones (7a-f), the hydrazone were cyclized to oxadiazoles (8a-f) by their reaction in the presence lead dioxide, the hydrazones (7a-f) showed IR spectra at 3296$3445 \mathrm{~cm}^{-1} \mathrm{~N}-\mathrm{H}, 1625-1672 \mathrm{~cm}^{-1} \mathrm{C}=\mathrm{O}$ and 1593-1640 $\mathrm{cm}^{-1} \mathrm{C}=\mathrm{N}$ stretching vibration.

The IR absorption spectra of oxadiazole (8a-f) showed the following bands (3290-3435), (1647-1672), (1605-1646) and (1205-1229) $\mathrm{cm}^{-1}$ assigned to $\mathrm{NH}$ stretching, $\mathrm{C}=\mathrm{O}$ stretching, $\mathrm{C}=\mathrm{N}$ stretching and combination band of C-O-C stretching vibrations, respectively. scheme:

The mechanism could be visualized according to following

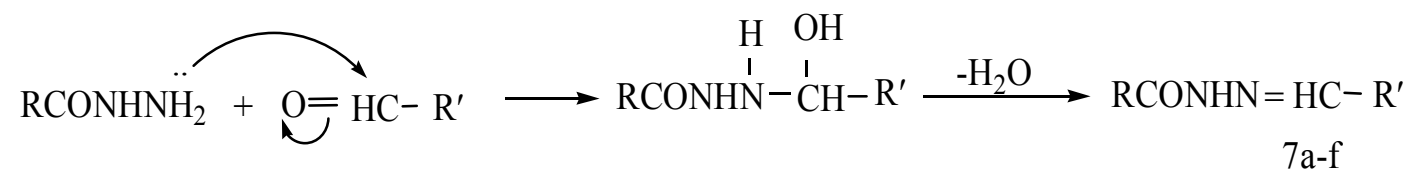<smiles>[R]CN(C[R])NC[C@H](C)O</smiles>

Tosyl-NHCHRCONHCHR' $=\mathrm{R}$<smiles></smiles>

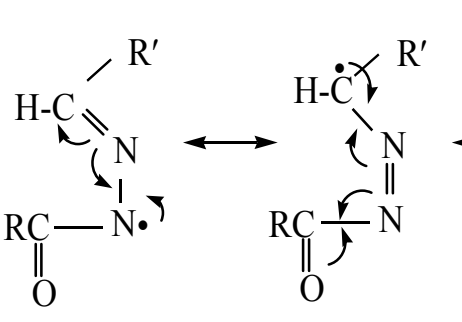

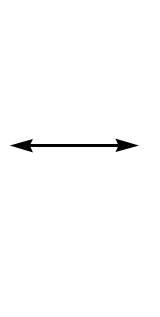<smiles>[R]C1=NN=C([R])C1O</smiles><smiles></smiles><smiles></smiles>

Table (1): Physical Properties and Spectral data of compounds amino acid Esters, amides and hydrazides

\begin{tabular}{|c|c|c|c|c|c|c|c|c|c|}
\hline \multirow{2}{*}{$\begin{array}{c}\text { Comp. } \\
\text { No. }\end{array}$} & \multirow{2}{*}{$\stackrel{\text { M.P. }}{{ }^{\circ} \mathrm{C}}$} & \multirow{2}{*}{ Color } & \multirow{2}{*}{$\begin{array}{c}\text { Yield } \\
\%\end{array}$} & \multicolumn{5}{|c|}{ I.R. $(\mathrm{KBr}) \mathrm{cm}^{-1}$} & \multirow{2}{*}{$\begin{array}{c}\mathrm{UV} \\
\mathrm{CHCl}_{3} \\
\lambda \underset{\max }{\mathrm{nm}}\end{array}$} \\
\hline & & & & $v_{\mathrm{NH}}$ & $\begin{array}{l}v_{\mathrm{C}-\mathrm{H}} \\
\text { arom }\end{array}$ & $\begin{array}{l}v_{C-H} \\
\text { ali. }\end{array}$ & $\begin{array}{l}v_{\mathrm{C}=\mathrm{O}} \\
\text { ester }\end{array}$ & $\begin{array}{c}\mathrm{v}_{\mathrm{C}=\mathrm{O}} \\
\text { amide }\end{array}$ & \\
\hline $3 \mathrm{a}$ & $\begin{array}{l}180- \\
182\end{array}$ & White & 92 & 3287 & 3060 & 2930 & 1747 & 1673 & 333 \\
\hline $3 b$ & $\begin{array}{l}178- \\
180\end{array}$ & White & 90 & 3306 & 3059 & 2932 & 1710 & 1673 & 330 \\
\hline $3 c$ & $\begin{array}{l}184- \\
185\end{array}$ & White & 93 & 3306 & 3060 & 2932 & 1716 & 1670 & 332 \\
\hline $4 a$ & $\begin{array}{l}153- \\
155\end{array}$ & White & 63 & 3306 & 3047 & 2930 & ---- & 1673 & 336 \\
\hline
\end{tabular}


Synthesis of Some 1, 3, 4- Oxadizole Derivatives From Naproxen and Acetyl ...

\begin{tabular}{||c||c||c|c||c||c||c||c||c|c||}
\hline \hline $4 \mathrm{~b}$ & $\begin{array}{c}189- \\
192\end{array}$ & White & 68 & 3306 & 3050 & 2931 & ---- & 1673 & 333 \\
\hline \hline $4 \mathrm{c}$ & $\begin{array}{c}176- \\
178\end{array}$ & White & 74 & 3303 & 3047 & 2931 & ---- & 1673 & 333 \\
\hline $5 \mathrm{a}$ & $\begin{array}{c}125- \\
127\end{array}$ & $\begin{array}{c}\text { Pale } \\
\text { Brown }\end{array}$ & 84 & 3331 & 3056 & 2929 & --- & 1627 & 333 \\
\hline \hline $5 \mathrm{~b}$ & $\begin{array}{c}172- \\
174\end{array}$ & $\begin{array}{c}\text { Pale } \\
\text { Brown }\end{array}$ & 87 & 3292 & 3050 & 2933 & ---- & 1651 & 333 \\
\hline \hline $5 \mathrm{c}$ & $\begin{array}{c}152- \\
155\end{array}$ & $\begin{array}{c}\text { Pale } \\
\text { Brown }\end{array}$ & 83 & 3297 & 3060 & 2930 & ---- & 1652 & 333 \\
\hline
\end{tabular}

Table (2): Physical Properties and Spectral data of compounds (6a-f), (7a-f) And (8a-f)

\begin{tabular}{|c|c|c|c|c|c|c|c|c|c|c|}
\hline \multirow{2}{*}{$\begin{array}{c}\text { comp. } \\
\text { No. }\end{array}$} & \multirow{2}{*}{$\begin{array}{l}\text { M.P. } \\
{ }^{\circ} \mathrm{C}\end{array}$} & \multirow[b]{2}{*}{ Color } & \multirow{2}{*}{$\begin{array}{c}\text { Yield } \\
\%\end{array}$} & \multicolumn{6}{|c|}{ I.R. $(\mathrm{KBr}) \mathrm{cm}^{-1}$} & \multirow{2}{*}{$\begin{array}{c}\mathrm{UV} \\
\mathrm{CHCl}_{3} \\
\lambda \max \\
\mathrm{nm} \\
\end{array}$} \\
\hline & & & & $\mathbf{v}_{\mathrm{NH}}$ & $\boldsymbol{v}_{\mathbf{C}=\mathbf{O}}$ & $\begin{array}{c}v \\
\mathbf{C}=\mathbf{N}\end{array}$ & $\begin{array}{c}v \\
\text { COC }\end{array}$ & $v \mathbf{C}=\mathbf{S}$ & $\begin{array}{c}v \\
\text { Other }\end{array}$ & \\
\hline $6 a$ & $140-143$ & $\begin{array}{c}\text { Peel } \\
\text { yellow }\end{array}$ & 67 & 3319 & 1629 & 1607 & 1213 & 1196 & --- & 333 \\
\hline $6 b$ & $170-173$ & $\begin{array}{c}\text { Peel } \\
\text { yellow }\end{array}$ & 68 & 3297 & 1652 & 1607 & 1227 & 1118 & --- & 333 \\
\hline $6 c$ & $168-171$ & $\begin{array}{c}\text { Peel } \\
\text { yellow }\end{array}$ & 64 & 3324 & 1651 & 1627 & 1227 & 1170 & --- & 333 \\
\hline $6 d$ & $175-177$ & yellow & 66 & 3336 & 1702 & 1624 & 1243 & 1163 & --- & 350 \\
\hline $6 e$ & $232-235$ & $\begin{array}{c}\text { Peel } \\
\text { yellow }\end{array}$ & 66 & 3369 & 1672 & 1656 & 1295 & 1142 & --- & 338 \\
\hline $6 f$ & $183-185$ & $\begin{array}{l}\text { Deep } \\
\text { yellow }\end{array}$ & 64 & 3444 & 1660 & 1625 & 1246 & 1117 & $\begin{array}{l}3200 \\
(\mathrm{OH})\end{array}$ & 342 \\
\hline $7 \mathrm{a}$ & $184-150$ & yellow & 71 & 3303 & 1663 & 1640 & --- & --- & --- & 299 \\
\hline $7 b$ & $168-171$ & yellow & 66 & 3300 & 1652 & 1605 & --- & --- & --- & 329 \\
\hline $7 c$ & $172-174$ & $\begin{array}{c}\text { Peel } \\
\text { yellow }\end{array}$ & 67 & 3323 & 1651 & 1627 & --- & --- & --- & 332 \\
\hline $7 d$ & $210-212$ & yellow & 61 & 3445 & 1625 & 1593 & --- & --- & --- & 337 \\
\hline $7 e$ & $224-226$ & $\begin{array}{c}\text { Peel } \\
\text { yellow }\end{array}$ & 86 & 3290 & 1672 & 1646 & --- & --- & --- & 292 \\
\hline $7 f$ & $225-227$ & White & 67 & 3286 & 1662 & 1610 & --- & --- & $\begin{array}{l}3220 \\
(\mathrm{OH})\end{array}$ & 312 \\
\hline $8 a$ & $138-140$ & Brown & 86 & 3327 & 1660 & 1628 & 1229 & --- & --- & 292 \\
\hline $8 b$ & $143-145$ & $\begin{array}{c}\text { Peel } \\
\text { yellow }\end{array}$ & 82 & 3299 & 1653 & 1605 & 1227 & --- & --- & 329 \\
\hline $8 \mathrm{c}$ & $130-132$ & White & 75 & 3321 & 1650 & 1629 & 1227 & --- & --- & 285 \\
\hline $8 \mathrm{~d}$ & $210-212$ & yellow & 69 & 3435 & 1647 & 1625 & 1211 & --- & --- & 332 \\
\hline $8 \mathrm{e}$ & $238-240$ & $\begin{array}{c}\text { Peel } \\
\text { brown }\end{array}$ & 85 & 3290 & 1672 & 1646 & 1205 & --- & --- & 306 \\
\hline $8 \mathrm{f}$ & $121-214$ & $\begin{array}{c}\text { Peel } \\
\text { brown }\end{array}$ & 90 & 3340 & 1659 & 1625 & 1207 & --- & $\begin{array}{l}3287 \\
(\mathrm{OH}) \\
\end{array}$ & 332 \\
\hline
\end{tabular}




\section{References}

1) J.Salimon, N.Salih and H.Hussien, 2011, Sains Malaysian a, 40(5), 445.

2) P.V.Frank, k, S.Girish and B.Kalluraya, 2007, J.Chem.Sci, 119, 41.

3) B.P.Navin and C.P.Jaymin, 2010, Sci pharm, 78(2), 171.

4) R.R.Somant, P.Y.Shirodkar and V.J.Kadam, 2008, Lett. Drug Desi. Disco, 5, 348.

5) X. Ouyang, E. Patnitski, 2006, Med. Chem. Lett. 16, 1191.

6) S.Bhandari, K.G. Bothara M.K. Raut, A.A.Patil, A.P. Sarkate and V.J. Mokale, 2008, Bioorg. Med. Chem., 16, 1822.

7) S.G. Kucukguzel, I. Kucukguzel, E. Tatar, S. Rollas, F. Sahin, M. Gulluce, E. De. Clercq and L. Kabasakal, 2007, Eur. J. Med. Chem. 42, 893.

8) Z. Muhammad, I. Rashid, A.A. Najim, H.Z. Javid and A.Muhammad, 2007, Chem. Inform, 38.

9) R.R. Somani, A.G. Agrawul, P.P. Kalantri, P.S. Gavarkar and E. De clercq, 2011, Lett. Drug Desi and Disco, 2, 1, 353.

10) L.D.S. Yadav, S. Saigal and S. Shukla, 1996, Indian J. Chem. 35B. 385 .

11) M.A. Ali and M.S. Yar, 2007, Bioorganic and Medicinal Chemistry Letters, 17, 3314.

12) A. Zarghi, S.A. Tabatabai, M. Faizi, A. Ahadian, P. Navabi, V Zanganeh and Shafiee, 2005, Bioorganic and Medicinal Chemistry Letters, 15, 1863.

13) M.A. Ali, M.S. Yar, 2007, Bioorganic. Med. Chem. Lett, 17, 3314.

14) A. Zargahi, S.A. Tabalabai, M. Faizi, A. Ahadian, P. Navabi, V. Zanganeh and A. Shafiee, 2005, bioorganic. Med. Chem. Lett. 15, 1863.

15) N.M. Bezerra, S.P. De- Oliveira, R.M. Srivastava and J.R. Dasilva, 2005, Farmaco., 60, 955.

16) M. Zareef, R. Iqbal, N.G. De Dominquez, J. Rodrigues, J.H. Zaidi M. Arfan and C.T. Supuran, 2007, J. Enzyme Inhib, Med. Chem. $22,301$. 
17) T.M. Tan, Y. Chem, K.H. Kang, Y. Baili, S.G. Lim, T.H. Ang and Y. Lam. 2006, Antiviral Res., 71, 7.

18) P.X. Hui, H.C. Chu, Y.Z. Zhang, Q. Wang and Q. Zhang, 2002, Indian J. Chem., 41B, 2176.

19) R. Deskmukh, A.K. Jha, A.S. Thakur and D. Dewangan, 2011, J. Res. Pharm. And Biomedical Sci., 2(1), 215.

20) A.S. Khanum. S. Shashikanth, S.B. Sudha, A.S. Deepak and S.H. Shetty, 2004, Pest Manag. Sci, 60, 1119.

21) B. Narayana, K.K. Vijayraj, B.V. Ashalatha and N.S. Kumari, 2005, Arch. Pharm (Weinheim), 338, 373.

22) M. Amir, S. Kumar, 2007, Acta Pharm, 31, 57.

23) H. A. Basheer, 2000, Ph. D. Thesis University of Mosul, Mosul, Iraq.

24) V.M. Rodionov and V.V. Kiseleva, 1951, Otdel. Khim. Nauk, 57, Chem. abs. 1952, 46, 466.

25) G. Werber, F. Buccheri, R. Noto and Gentile, 1977, J. Heterocyclic Chem., 14, 1385.

26) R. S. Sharma and S.C. Bahel, 1982, J. Indian Chem. Soc., LIX, 877.

27) M.M. Dutta, B.N. Joswami and J.C.S. Kataky, 1986, J. Heterocyclic Chem., 23, 793.

28) R.W. Young and K.H. Wood, 1955, J. Am. Chem. Soc., 77, 400. 